Pyvovar, S.F. (2021). Russian SS in the German-Soviet war of 1941-1945. Rethinking of history: conflict of facts and hypotheses. Collection of Scientific Articles. European Scientific e-Journal, 7 (13), 80-101. Hlučín: "Anisiia Tomanek" OSVČ. (in Ukrainian)

Пивовар, С.Ф. (2021). Російські есесівці у німецько-раАянській війні 1941-1945 років. Retbinking of history: conflict of facts and hypotheses. Collection of Scientific Articles. European Scientific e-Journal, 7 (13), 80-101. Hlučín: "Anisiia Tomanek" OSVČ.

DOI: $10.47451 /$ his2021-06-001

EOI: 10.11244/his2021-06-001

The paper is published in Crossref, Internet Archive, Google Scholar, Academic Resource Index ResearchBib, JGate, ISI, CiteFactor, ICI, eLibrary databases.

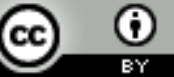

Serhii F. Pyvovar

Candidate of Historical Sciences, Professor

Professor of the Department of Modern History of Ukraine

Faculty of History

Taras Shevchenko National University of Kyiv

Kyiv, Ukraine

E-mail: histfac@knu.ua

\title{
Russian SS in the German-Soviet war of 1941-1945
}

Abstract:

The article analyzes the problem of cooperation between Russians and the Nazi SS organization during the war between Germany and the Soviet Union in 1941-1945. The research is based on the dialectical and systematic approaches to scientific research, as well as the principles of scientificity, historicism and objectivity. To reveal this topic, published collections of documents and materials, memoirs of participants in the events, scientific research of scientists from different countries were used. The article reveals the essence and forms of cooperation of Russians with various bodies, divisions and formations of the SS. It was established that the participation of Russians in the activities of the SS took various forms - from propaganda, reconnaissance and sabotage work to participation in hostilities on various fronts of the Second World War. It is emphasized that Russian youth - "pupils of the SS" were also involved in the work in the ranks of the SS. It is proved that the SS leadership controlled the process of formation and activity of the Russian liberation movement. Researchers' estimates for determining the number of Russian SS members are analyzed.

Keywords:

SS troops, prisoners of war, volunteers, collaborationism, German-Soviet war, Russian SS.

Сергій Федорович Пивовар кандилат історичних наук, професор професор кафедри новітньої історії України

Історичний факультет

Київський національний університет імені Тараса Шевченка, Київ, Україна 


\title{
Російські есесівці у німецько-радянській війні 1941-1945 років
}

\begin{abstract}
Aнотачія:
У статті аналізується проблема співпраці росіян з нацистською організацією СС під час війни між Німеччиною та Радянським Союзом у 1941-1945 рр. Основу АосліАження становцять Аіалектичний та системний піАходи АО наукового пошуку, а також - принципи науковості, історизму й об'єктивності. Аیя розкриття зазначеної теми використано опубліковані збірники документів і матеріалів, спогади учасників подій, наукові дослідження учених різних країн. Стаття розкриває сутність і форми співробітництва росіян з різними органами, пілрозділами та формуваннями СС. Встановлено, що участь росіян в діяльності СС набула різних форм - віА пропагандистської, розвіАувальної та Аиверсійної роботи Ао участі у бойових Аіях на різних фронтах Аругої світової війни. ПіАкреслюеться, що Ао роботи у мавах СС залучалася також російська молодь - «вихованці СС». Аоведено, що керівництво СС контролювало процес становлення та діяльності Російського визвольного руху. Проаналізовано оцінки досліАників щодо визначення кількості російських есесівців.
\end{abstract}

\section{Ключові слова:}

війська СС, військовополонені, Аобровольці, колабораціонізм, німецько-радянська війна, російські есесівці.

\section{Список скорочень}

АК - Армія Крайова

БСРН - Бойовий союз російських націоналістів

ГУКВ - Головне управління козацьких військ

3С КВНР - Збройні сили Комітету визволення народів Росії

КВНР - Комітет визволення народів Росії

МBC - Міністерство внутрішніх справ

НПРН - Національна партія російського народу

НТС - Народно-трудовий союз

НКВС - Народний комісаріат внутрішніх справ

НСРПН - Націонал-соціалістична робітнича партія Німеччини

ППО - Протиповітряна оборона

ПЦББ - Політичний центр боротьби з більшовизмом

РВА - Російська визвольна армія

РВНА - Російська визвольна народна армія

РВР - Російський визвольний рух

РЗГА - Головне управління імперської безпеки Німеччини

РНПР - Російська народна партія реформістів 
РСЧА - Робітничо-селянська червона армія

СА - Штурмові загони

СА - Служба безпеки

СМЕРШ - (абревіатура початкових букв гасла «Смерть шпигунам!») піАрозділ контррозвіАки Народного комісаріату оборони СРСР

СРМ - Союз російської молоді

СРСР - Союз Радянських Соціалістичних Республік

СС - Військово-поліційна організація

\section{Вступ}

Актуальність теми дослідження. Співробітництво колишніх громадян СРСР $з$ нацистськими СС є одним з важливих, але маловивчених аспектів історії радянського колабораціонізму, масштаби якого в роки німецькорадянської війни були величезними. Сучасні АосліАники піАрахували, що загалом на німецький окупаційний режим працювало 22 млн раАянських громадян (Ермолов, 2010). Водночас за цей період командування Німеччини сформувало 180 окремих частин і з’єАнань з громадян СРСР, чисельність яких становица майже 2 млн осіб (Похлёбкин, 1997). Раніше історія цюдства не знала таких масштабів зради власної держави і переходу на бік ворога.

Автори книги 3 характерною назвою «Російські есесівці в бою...» в анотації до своєї праці зазначають, що саме словосполучення «російські есесівці ... ріже слух своєю протиприродністю» (Жуков й Ковтун, 2009). Насправді, це явище має своє пояснення. Ажерела і причини співробітництва росіян з СС необхіАно шукати у складній і суперечливій ситуаціі, що склалася в СРСР у результаті здійснення комуністичного експерименту в 1917-1941 рр.

Об'єкт АосліАження - співпраця етнічних росіян 3 різними структурами нацистських СС у роки німецько-раАянської війни 1941-1945 рр.

Метою статті $є$ аналіз сутності, змісту та форм співробітництва росіян громадян СРСР - у різних структурах, які входили Ао склаАу СС у періол німецько-радянської війни 1941-1945 рр.

Матеріали та методи дослідження. Аля розкриття теми співробітництва росіян з нацистськими СС використано опубліковані збірники документів і матеріалів, спогаАи учасників подій, наукові досліАження захіАних, українських i російських учених. Залучені Ажерела та мітература Аозволяють реконструювати процес співпраці росіян з різними структурами СС.

АосліАження грунтується на хронологічно-проблемному принципі викладу матеріацу. Теоретичною основою статті $є$ загацьноприйняті в 
історичній науці методи: науковість та об’єктивність. Керуючись принципом історизму, співробітництво росіян з СС розгляАається у зв'язку з конкретними історичними обставинами, які обумовили це явище й впливали на його еволюцію. У ході аналізу Ажерел і літератури застосовано критичний піАхіА, зАійснена спроба уникнення однобічних оцінок. Принцип системного піАхоАу АОзволив розглянути участь етнічних росіян у різних структурах СС крізь призму єАності всіх компонентів предмету досліАження. Завдяки застосуванню аналізу вАалося визначити основні напрямки військової Аіяльності російських збройних формувань у складі СС і розглянути еволюцію ставлення до них німецького керівництва. Метод синтезу допоміг виділити основні періоди створення різних структур СС спеціального призначення, Ао скАаАу яких входили росіяни, і охарактеризувати їх розвиток. Хронологічний та історикоаналітичний методи Аозволили викласти матеріал у чіткій посліАовності та могічній завершеності.

Стан наукового вивчення співробітництва росіян 3 СС можна охарактеризувати як малодосліАжену й дискусійну проблему. ЗахіАні вчені у своїх досліАженнях звертали увагу передусім на діяльність СС загалом, а не на етнічну приналежність особового скцаАу. Найбільший внесок у наукову розробку вказаної проблематики зробили російські вчені $А$. Жуков й І. Ковтун, які у співавторстві видали кілька праць, присвячених різним аспектам Аіяльності російських есесівців (Жуков і Ковтун, 2019; Жуков і Ковтун, 2013); Жуков і Ковтун, 2010; Жуков і Ковтун, 2009). 3 українських АосліАників зазначеної проблеми насампереА сліА виАілити наукові праці А. Боляновського (Боляновський, 2013; Боляновський, 2014; Боляновський, 2012).

ОАнак, незважаючи на певну кількість праць, присвячених історії співробітництва росіян з СС, ця проблема потребує подальшого АосліАження, з'ясування окремих аспектів, уточнення Аеяких фактів, узагальнення та систематизації розрізненої інформації.

Практичне значення результатів досліАження полягає в можливості використання наведених у ньому матеріалів і висновків Аля написання наукових праць, навчальних піАручників і посібників з історії Аругої світової війни.

\section{ВикцаА основного матеріалу}

СереА спецслужб нацистської Німеччини особливе місце посіАає військово-поліційна організація CC (SS), яка була утворена у 1925 р. як охоронні загони НСРПН (Schutzstaffeln der NSDAP). У 1932 р. виникла нацистська служба безпеки CА (Sicherheinstsdienst - SD). Спочатку вона була 
розвіАувальним віАлілом СС, згодом перетворицася на партійну гвардію, стала важливою складовою організації поліції безпеки і СА, а загалом, за висловом німецьких дослідників Г. Кіндера і В. Хільгемана, являла собою «державу СС» (Киндер і Хильгеман, 2003). Після «ночі довгих ножів», 30 червня 1934 р., в результаті чого штурмові загони (Sturmabteilung - SA) втратили своє значення, СС стала незалежною партійною організацією, очолюваною райхсфюрером СС Генріхом Гіммлером, який не піАлягав жодному органу влади. 17 червня 1936 р. він був призначений начальником німецької поліції у МBC, а 26 червня видав декрет, згілно з яким кримінальна поліція - Кріпо (Kriminalpolizei Kripo) і таємна Аержавна поліція - Гестапо (Geheime Staatspolize - Gestapo) увійшли до склалу державної поліції безпеки - Сіпо (Sicherheitspolizei - SiPo) й об’єАналися з партійною СА піл керівництвом Райнгарда Гейдріха. 27 вересня 1939 р. ці структури утворили оАне аАміністративне ціле - РЗГА - Головне управління імперської безпеки (Reichssicherheitshauptamt - RSHA). РЗГА було одним з найважливіших головних управлінь CС, яке поділялося на 7 вілАілів. Крім охоронно-поліційних вілділів у структурі СС у 1939 р. було створено бойові формування - «Збройні CC» (Waffen-SS). На окупованих територіях СРСР, які розглядались як райони воєнних Аій, члени Сіпо і СА об’єАнувалися в спеціальні каральні загони військового типу, віломі піА назвами айнзатцгруп (Einsatzgruppen der Sicherheitspolizei und des SD), які склаАалися 3 айнзатцкоманд (Einsatzkommando) або зондеркоманд (Sonderkommando). Їхнє завАання полягало в тому, щоб гарантувати «політичну безпеку» в зоні бойових Аій та в зоні тилу (Косик, 1996). Натомість члени поліції порядку, особовий скцаА військ СС використовувались як Аопоміжна сила. Всі ці організації перебували піА загальним контролем РЗГА і піАпоряАковувалися райхсфюреру СС Г. Гіммлеру, але в районах воєнних Аій - оперативному командуванню віАповіАної армії (СС в действии. Аокументы о преступлениях СС, 1960). Отже, широко розгалужена структура СС поєАнувала різні органи, піАрозділи та формування. Спочатку до їх складу входили мише німці, але в роки Аругої світової війни СС поповнювацася представниками різних націй, у т. ч. етнічними росіянами.

Першими росіянами, які почали співробітничати з СС, були емігранти, які залишили Росію ще піА час Революції та Громадянської війни 1917-1922 рр. Початок німецько-раАянської війни вони сприйняли як продовження боротьби проти більшовицького режиму, сподіваючись на визволення віА нього своєї батьківщини і встановлення в Росії нового, справедливого малу. За цих умов участь представників російської еміграції у Аіяльності різних структур СС 
значно активізувалась, набула різних форм і продовжувалася до травня 1945 р. ОАнак, значно більший потенціал Аля співробітництва з СС у роки німецькорадянської війни виявився сереА росіян, які до війни були громадянами СРСР.

16 мипня 1941 р. на нараді з керівниками III Райху ААольф Гітлер вимагав «ніколи не Аозволяти, щоб хтось інший, окрім німців, носив зброю», не Аопускати виникнення місцевих збройних сил на захіА віА Уралу, «навіть якщо за це нам доведеться воювати цілих сто років» (Косик, 1996; Семиряга, 2000). Проте, провал операції «Барбаросса» змусив Берлін змінювати свою політику на Сході.

3 початком німецько-радянської війни за ініціативи бригаденфюрера СС ОАіла ГАобочника в м. Травники було віАкрито навчальний табір (SSAusbildungslager Trawniki), який мав стати опорним пунктом СС і поліції у східних областях. 3 метою вербування необхідних кадрів упродовж серпнявересня 1941 р. штурбанфюрер СС Карл Штрайбель зАійснював поїздку таборами Аля радянських військовополонених. У результаті вже Ао кінця року на навчальній базі перебувала 1 тис. осіб. Всі кандиАати піАписували заяви про Аобровільний вступ Ао загонів СС. Навчальний процес зАійснювався на основі програми, прийнятій у частинах СC «Мертва голова» (SS-Totenkopfverbände) спеціальних військових з'єАнань, створених Аля охорони концентраційних таборів. Вона передбачала спеціальну піАготовку вахманів СС - охоронців Аля концтаборів і в'язниць, а також Аля зАійснення поліційно-каральних операцій. За час свого існування з жовтня 1941 р. Ао листопада 1943 р. у таборі Травники було піАготовлено 5082 охоронців. Встановити сереА цих охоронних кацрів точну чисельність етнічних росіян, які піА час вербування видавали себе за білорусів чи українців, досліАникам не вАалося. Зрештою більшість «травників» потрапила Ао рук СМЕРШу й була страчена (Жуков і Ковтун, 2009).

Аля подальшої боротьби з СРСР у Берліні було ухвалено рішення залучити VI управління (SD-Ausland - зовнішня розвіАка) РЗГА. Його начальник Вальтер Шелменберг отримав наказ організовувати в радянському тилу секретну резилентуру і направляти ії роботу. 3 цією метою у березні 1942 p. у структурі VI управління було створено спеціальний розвіАувальноАиверсійний орган «Цеппелін» (Unternehmen Zeppelin), який очолив спочатку оберштурмбанфюрер СС Аоктор Гайнц Грейфе, 3 мипня 1942 р. штандартенфюрер СС Рудольф фон Ебсгер-Рьодер, а з березня 1943 р. штандартенфюрер СС Вальтер Куррек (Гетьманчук, 2018). У своїй Аіяльності «Цеппелін» керувався «Планом дій щодо політичного розклаАу РаАянського Союзу», в якому вказувалося, що організація «е органом ведення політичної 
розвіАки і диверсійної роботи в тилу СРСР». Аля цього створювалися спеціальні групи: розвіАувацьні, Аиверсійні, повстанські та пропагандистські (Чуев, 2003). За свілченням В. Шелменберга, головна мета «Цеппеліна» «зводилася Ао Аесантування у глибокий тил РаА військових піАрозАінів, набраних 3 російських військовополонених». Навесні 1943 р. замість зондеркоманА було створено Головні команди (Hauptkommando): «РосіяЦентр», перейменована у серпні 1943 р. на «Росія-Північ», і «Росія-Південь». Перед ними ставилось завдання здійснювати «саботаж, політичні акції й збирання інформації» (Шемленберг, 1991). Оскільки через проблеми 3 мюфтваффе щодо віАправки диверсантів за мінію фронту постійно виникали затримки, цих агентів, згіАно з твердженням В. Шемленберга, «організували у так звані бойові «Аружини» і зобов’язали їх наАавати допомогу в піАтриманні порядку в тилу i, в разі потреби, вступати у боротьбу з партизанами». Командиром однієї з таких Аружин, призначили «російського полковника на прізвище Родіонов, віАомого піА прізвиськом Ажіл...» (Шелменберг, 1991). ЙАеться про колишнього начальника штабу 229-ї стрілецької Аивізії РСЧА піАполковника Володимира Гіля (псевдонім «Родіонов»). Ще восени 1941 р. він очолив антибільшовицьку НПРН, Ао склаАу якої увійшли раАянські військовополонені командири табору № 68 у м. Сувалки. Цей табір перебував у віданні СА, а В. Гіль виконував обов'язки російського коменданта. У квітні 1942 р. там було створено БСРН. Згодом російськими націоналістами зацікавилися співробітники «Цеппеліна», які пілбирали калри Аля розвілувально-диверсійної роботи. На основі БСРН було сформовано загін «Аружина» чисельністю бл. 500 осіб. Позитивно зарекомендувавши себе в боях 3 польськими партизанами у районі Аюбліна, «Аружина» була передислокована на окуповану радянську територію піА Смоленськ (Аробязко, 1999).

У груані 1942 р. в особливому таборі СС «Гайлов» поблизу Аюбліна було сформовано «Аружину ІІ» чисельністю бл. 300 осіб піА командуванням колишнього капітана РСЧА АнАрія Блажевича. У березні 1943 р. обилва загони, а також Аиверсійний загін із розвілувальної школи у м. Волау й «Особливий російський батальйон СС», сформований у м. Бреслау, об’єАнали в «1-й Російський національний полк СС» (1. Russisches Nationale SS-Regiment), який у квітні 1943 р. переформували в «1-у Російську національну бригалу СС («Дружина»)». Командирами були призначені В. Гіль-Родіонов і А. Блажевич, які отримали звання штандартенфюрерів СС. При штабі бригаАи Аіяв німецький штаб зв’язку, очолюваний гауптштурмфюрером СС ЕААі Рознером. 
Після додаткової мобілізації місцевого населення чисельність новоутвореного з’єАнання у мипні 1943 р. сягнула 3 тис. вояків. 20\% з них були колишніми військовополоненими, а 80\% - поліцейські та мобілізоване місцеве населення (Аробязко та інші, 2011). Російська бригада піАпорядковувалася СА, а особовий склаА носив уніформу та знаки віАмінності аналогічні тим, що були прийняті у військах СС (мундир сірого кольору з орлом на мівому рукаві, брюки і пілотки 3 «мертвою головою», коричневі сорочки 3 краваткою). Крім того, вояки «Аружини» носили нарукавну стрічку з написом «За Русь!».

Сліл піАкреслити, що в цей час відбувалась переорієнтація головного завдання підготовки російських есесівців 3 Аиверсійної Аіяльності на антипартизанську. ВіАповіАно головним завданням бригади СС «Аружина» була боротьба з радянськими партизанами. ОАнак, 16 серпня 1943 р. 2,2 тис. російських есесівців перейшли на бік радянських партизан й утворили 1-у Антифашистську партизанську бригаду піл командуванням того ж В. Гіля. У подальшому тепер уже колишні російські есесівці спільно 3 радянськими партизанами воювали проти німців. Проте у квітні-травні 1944 р., зазнавши значних втрат у боях з антипартизанськими загонами СС і поліції, бригада припинила своє існування. Вірність нацистам зберегли бл. 500 російських есесівців (Жуков, 2014). Залишки з’єАнання були передані головній команді «Росія-Північ» і використовувались як каральний загін і резервна база Аля вербування агентури (Сборник справочных материалов, 2012).

«Цеппелін» співробітничав і 3 іншими колабораціоністськими російськими формуваннями. Так, навесні 1942 р. у таборі Аля військовополонених у м. Веймарі за ініціативи колишнього раАянського генерала Івана Бессонова була створена РНПР. Його керівництво перевели Ао особливого табору «Цеппеліна» у Бухенвальді, де утворився ПЦББ. Спочатку ПЦББ видавав і поширював серед радянських військовополонених агітаційнопропагандистські газети i журнали. 3 часом I. Бессонов запропонував керівництву «Цеппеліна» співробітництво в переправ енні Аиверсійного загону у раАянський тиц. 3 цією метою групі І. Бессонова було віАведено спеціальний табір поблизу м. Бреславль, а на початку 1943 р. перевелено до м. Аінслорф. Кандилатів до загону керівництво ПЦББ вербувало серед військовополонених (Сборник справочных материалов, 2012). Після закінчення війни генерал КВНР Михайло Меандров у своїх показах свіАчив, що з метою Аіяльності на окупованій території СРСР з членів ПЦББ також було створено карацьний загін, який очолив цейтенант СС Фюрст (Генерал Власов: история

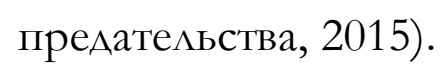


Навесні 1943 р. було створено «СС зондтабір «ЗанАберг», який спочатку виконував функції перевірки та фільтрації, а з 1944 р. почав готувати кваліфіковану агентуру Аля забезпечення кадрів головних команд «Цеппеліна» (Русские в Предприятии «Цеппелин», 2009). Ао цього табору було направлено гаупштурмфюрера Михайла Семенова, який ще з 1941 р. співробітничав з VI управлінням РЗГА. Йому Аоручили сформувати російський полк СС, який згодом отримав назву Аобровольчий полк СС «Варяг» (Freiwilligen SSSonderregiment «Warager»). Основу полку склали російські емігранти Аобровольці, завербовані в Югославії, а також радянські військовополонені (Чуев, 2003). Ао кінця 1944 р. чисельність полку становила 2,5 тис. вояків. Російські есесівці полку «Варяг» брали участь у бойових Аіях проти югославських партизан. М. Семенов отримав звання штандартенфюрера СС і був нагороджений Залізними хрестами I і II ступеня (Жуков і Ковтун, 2009).

Отже, впродовж 1942-1944 рр. росіяни брали активну участь у діяльності розвіАувально-Аиверсійного органу VI управління РЗГА «Цеппелін», Аопомагаючи нацистській Німеччині в зАійсненні розвіАки, Аиверсій, пропаганди, а також - у боротьбі з партизанами. У 1944-1945 рр. школи і піАрозділи «Цеппеліна» були реформовані й перегруповані.

За наказом Г. Гіммлера віА 6 мистопада 1941 р. всі охоронні та поліцейські частини, сформовані з добровольців і військовополонених на окупованій території були об’єАнані у Аопоміжну службу поліщії порядку (Schutzmannschaft der Ordnungspolizei) (Генерал ВАасов: история предательства, 2015). Командувачами поліції порядку та поліції безпеки СА і, віАповіАно, всіма загонами СС і піАрозділами поліції порядку, а також місцевою поліцією безпеки і СА, керували вищі фюрери СC і поліції (Hohere SS und Polizeifuhrer), які піАпорядковувались особисто Г. Гіммлеру. Отже, створення й функціонування допоміжної поліції на окупованій території поклаАалося на СС. За цих умов виникли особливі піАрозділи - шутцманшафти (Schutzmannschaft). Вони формувалися 3 місцевого населення і військовополонених і Аіяли під німецьким командуванням, згодом безпосередньо у складі СС. Аля російських і білоруських піАрозділів було встановлено нумерацію віА 51-го до 100-го. Проте, значна кількість росіян, які, прагнучі полегшити своє становище, вилавала себе за українців і білорусів, служила і в райхскомісаріатах «ОстланА» (нумерація від 1-го до 50-го) і «Україна» (віА 101-го Ао 200-го). Крім того, у Прибалтиці росіяни масово вступали на службу в так звані «латгальські батальйони» (з російського населення були створені 314-й і 315-й батальйони). Загалом, як стверАжують досліАники А. 
Жуков й І. Ковтун, «Аесятки тисяч росіян вступили у Аопоміжну поліцію, у різні формування поліції безпеки і СА» (Жуков і Ковтун, 2009).

1 серпня 1944 р. на основі розформованих білоруських шутцманшафтів у тилу групи армій «Центр» було створено загороджувальну бригаАу (Sperrbrigade) Аопоміжної поліції порядку «Зіглінг» (Schutzmannschaft-Brigade Siegling (SS-Polizei-Bataillon-Siegling), яку очолив оберштурмбанфюрер Ганс Зіглінг. За національним складом це формування було доволі строкатим. У ньому зібралися росіяни, білоруси, украӥнці, поляки, німці тощо. Проте переважну більшість вояків становили етнічні росіяни. АосліАник Б. Соколов наголошує, що хоча з'єАнання прийнято називати білоруським, за своїм особовим складом це були «в основному - колишні полонені російської національності» (Соколов, 2000). БригаАа Зіглінга склацалася 3 чотирьох полків, розміщених на території СхіАної Пруссіі. Спочатку переА нею поставили завдання допомагати вермахту стримувати наступ РСЧА. У серпні 1944 р. це з’єАнання передислокували до Франції Аля боротьби з партизанами. 18 серпня бригада була перетворена на 30-ту гренадерську дивізію СС (російську № 2) - 30. Waffen-Grenadier-Division der SS (russische Nr. 2). 24 жовтня Аивізію переформували, в результаті чого було створено три полки СС: 75-й (4-й російський) - Waffen-Grenadier-Regiment der SS Nr. 75 (russische Nr. 4); 76-й (5-й російський) - Waffen-Grenadier-Regiment der SS Nr. 76 (russische Nr. 5); 77-й (6-й російський) - Waffen-Grenadier-Regiment der SS Nr. 77 (russische Nr. 6); 30-й артилерійський Waffen-Artillerie-Regiment der SS Nr. 30 (russische Nr. 2) і ще кілька пілрозділів (Романько, 2008). Зрештою, через Аезертирство та бойові втрати на Захілному фронті у грудні 30-а дивізія СС була передислокована до Баварії.

Крім вищезгаланої 30-ї дивізї СС, була сформована також 29-а російська Аивізія СС, віАома як «бригада Камінського». Її становлення пов’язане з історією т. зв. Аокотської республіки, яка виникца ще на початку німецько-радянської війни. Це російське територіальне утворення 3 автономною аАміністрацією самоуправління мало власні збройні сили - РВНА, яка стала одним 3 найвідоміших збройних формувань, створених на території СРСР переважно 3 росіян. Хоча головним завданням РВНА була боротьба з партизанами, окремі iï пілрозділи брали участь у боях із РСЧА. Так, у березні 1943 р. три батальйони увійшли до склаАу бойової групи «Z» штандартенфюрера СС А. Цехендера (Аивізія СС «ФАоріан Гейєр») і протистояли 2-му гвардійському кавалерійському корпусу РСЧА піА м. Севськом. На початку 1944 р. після передислокації до ЗахіАної Білорусії РВНА була вкцючена як «штурмова бригада РВНА» Ао 
скцалу бойової групи обергруппенфюрера СС і генерала Ваффен СС Курта фон Готтберга. 27 січня за ефективну боротьбу з партизанами Б. Камінського нагородили Залізним хрестом II ступеня. Заслуги його бригади Аійсно були вагомими. Зокрема, РВНА розгромила вищезгадану 1-у Антифашистську бригаду - колишню 1-у російську національну бригаду СС «Аружина». Як стверджують досліАники, саме після успішних бойових Аій проти партизан на початку 1944 р. РВНА «міцно займає місце сереА частин і з’єАнань поліції і військ СС» (Жуков і Ковтун, 2009). Враховуючи цю обставину, 31 кипня 1944 р. РВНА була включена до складу військ СС як Штурмова бригада СС «РВНА». Б. Камінський отримав звання ваффен-бригаденфюрера і генерац-майора військ СС і поліціі, а також був нагороджений Залізним хрестом I ступеня. Російські офіцери також отримали звання СС, що віАповіАали їхнім званням у PВНА. А вже 1 серпня 1944 р. згіАно з наказом Головного оперативного управління CC (SS-Führungshauptamt - SS-FHA) бригалу переформували у повноцінну 29-у Ваффен-Гренадерську Аивізію СС «РВНА» (29. WaffenGrenadier-Division der SS «RONA» (Russische Nr. 1)). У зв’язку з отриманням Аивізійного статусу передбачалось формування 72-го, 73-го и 74-го гренаАерських полків, артилерійського полку, протитанкового батальйону, Аивізіону зенітної артилерії й інших підрозділів. Проте, запланованій реорганізації РВНА в есесівську дивізію стало на перешкоді повстання, яке АК розпочала 1 серпня у Варшаві. А. Гітлер наказав придушити повстання поляків силами військ СС. Г. Гіммлер наАіслав Б. Камінському термінову телеграму, в якій говорицося: «Чекаю Вашої допомоги у цій справі». Командувачем операцією призначили обергруппенфюрера СС Еріх фон дем Баха. Ао складу спеціального угруповання увійшли й пілрозділи 29-ї Аивізії СС. 3 кожного полку виАілили по 400 вояків і сформували зведений полк чисельністю бл. 1,7 тис. осіб. Командувати цим з’єднанням призначили оберштурмбанфюрера СС Івана Фролова. Звелений полк російських есесівців піАпорядковувався группенфюреру СС і генерал-лейтенанту військ СС i поліції Гайнцу Райнефарту, а з 9 серпня увійшов до складу бойової групи генерал-майора Гюнтера Рора. У ході вуличних боїв 3 польськими повстанцями полк РВНА втратив майже 500 осіб убитими, пораненими і такими, що пропали безвісти. Водночас «камінці» займалися грабежами і чинили жорстокості, що викАикало невдоволення у німецького команАування. Російських есесівців почали поступово виводити 3 міста Аля боротьби 3 польськими партизанами на околицях Варшави, хоча окремі пілрозділи полку продовжували вуличні бої до 28 серпня. Зрештою їхні позиції зайняли німецькі 
війська. За бойові Аії проти польських повстанців І. Фролова нагородили Залізним хрестом I ступеня (Русские эсэсовцы в боях за Варшаву, 2012).

Б. Камінський та його начальник штабу ваффен-оберштурмбанфюрер I. Шавикін також брали участь у бойових діях у Варшаві. Проте 19 серпня обоє були викликані в штаб фон дем Баха й по Аорозі зникли за остаточно нез'ясованих обставин. В історіографії існує кілька версій цієї загадкової події (Аив. Аокцадніше: ГАаубе, 2007; Пивовар, 2021). Після зникнення російських командирів 29-у Аивізію СС очолювали спочатку оберштумбанфюрер СС Георгій Бєлай, з 28 серпня - бригаденфюрер СС Крістоф Аім, з 27 вересня группенфюрер СС Генріх Юрс. У цей час бл. 3 тис. російських есесівців перебували у Нойхаммері, Ае створювалася 600-а піхотна російська Аивізія (ГАаубе, 2007). Інших «камінців» 30 вересня віАправили на приАушення Словацького національного повстання (Генерал ВАасов: история предательства, 2015).

ОАнак, спеціальна інспекція, яку здійснювали обергруппенфюрер СС Готтлоб Бергер, гауптштурфюрер СС Карл Альбрехт і ваффенунтерштурфюрер СС Анатолій Камінін, 11 жовтня визнала з'єАнання небоєздатним і таким, що підлягає розформуванню (Аробязко, 1999). Німецький історик Й. Гоффманн наголошує, що керівництво СС «віАмовилося віА початкового наміру переформувати бригаду в 29-у гренадерську Аивізію Ваффен СС... і передало його особовий склаА у розпоряАження Визвольної армії (Хоффманн, 1990). Водночас 72-й і 73-й полки увійшли до складу бригади Аілевангера.

На думку британського історика Кріса Бішопа, бригаАа Б. Камінського «набула найгіршої репутації сереА усіх частин СС» і тому «була розформована, навіть не приступивши до формування, а номер 29 передано італійській гренадерській дивізії СС» (Бишоп, 2009). Аійсно, у Берліні вирішили російських есесівців замінити на італійців, у результаті чого була сформована 29-та гренадерська дивізія СС «Тталія» (1-а італійська) (29. Waffen-GrenadierDivision der SS (italienische Nr. 1). Проте, слід уточнити, що офіційно італійське з'єАнання було створено Аише 10 Аютого, а 29-й номер присвоєно 9 березня $1945 \mathrm{p}$.

Крім двох офіщійно російських есесівських дивізіях росіяни воювали і в складі інших офіційно неросійських, зокрема в 36-й дивізії СС. Сформований у мипні 1940 р. як спеціальна команда на чолі з Оскаром Аірлевангером (SSSonderkommando «Dirlewanger»), цей піАрозділ був піАпорядкований CC i перейменований на батальйон CC (SS-Sonderbataillon «Dirlewanger»), а у вересні 
1943 р. - на полк (SS-Sonderregiment «Dirlewanger»). Спочатку зондеркоманда «Аірлевангер» комплектувалася мише 3 ув'язнених німецьких тюрем, але пізніше поповнювалася за рахунок «схілних добровольців», у тому числі 3 колишніх радянських військовополонених (Рейтлингер, 2011). ПіА час здійснення антипартизанських операцій на території Білорусії, приАушення Варшавського та Словацького повстань з'єднання О. Аірлевангера взаємодіяло з РВНА. У жовтні 1944 р. у розпорядження оберфюрера СС О. Аірлевангера командування передало 2 полки з розформованої російської 29-ї дивізії СС. 19 грудня це з'єАнання переформували в Штурмову бригаду СС, а 14 ^ютого 1945 p. - у Аивізію, яка стала 36-ю гренадерською дивізією Ваффен СС (36. WaffenGrenadier-Division der SS). Подальше поповнення особового складу дивізії відбувалося за рахунок військовополонених, у т. ч. росіян. К. Бішоп піАтверджує, що 36-а дивізія «мала в своїх мавах багато росіян, Аеякі з яких дезертирували з Червоної армії разом зі своїми танками» і тому в складі з'єАнання був танковий батальйон військ СС, оснащений радянськими танками Т-34 (Бишоп, 2009). Зрештою Аивізія потрапила в оточення піА Берліном і була знищена.

Кілька десятків росіян воювали у мавах 32-ї гренадерської дивізії військ СС «30 січня» (32. SS-Freiwilligen-Grenadier-Division «30. Januar»), яка була сформована в січні 1945 р. в навчальному таборі СС «Курмарк». Більша їх частина опинилася в саперному батальйоні з'єАнання, яким командував колишній мейтенант РСЧА унтерштурмфюрер СС Антонов (Гончаренко, 2005). У ^ютому 1945 р. ця дивізія увійшла Ао склаАу V армійського корпусу СС 9-ї армії групи армій «Вісла» і в березні була направ ена проти наступаючих раАянських військ на ОАері. Уцілілі залишки з'єАнання зАалися в полон союзникам 5 травня 1945 р. у Тангермюнде (Жуков і Ковтун, 2009).

Історик К. Семенов вказуе на «факт служби кількох тисяч російських жителів Аатвії й Естонії у мавах національних частин, у тому числі й у військах СС» (Семёнов, 2008). ОАин з них - ваффен-оберштурмбанфюрер Олександр Соболєв - командир артилерійського Аивізіону Естонської бригади військ СС, яка в січні 1944 р. була переформована на 20-у естонську гренадерську дивізію військ CC (20. Waffen-Grenadier-Division der SS (estnische Nr. 1) (Жуков і Ковтун, 2009).

Загалом наприкінці Аругої світової війни Війська СС налічували 39 Аивізій, через які, як стверджує К. Бішоп, «пройшло в цілому близько 1 мільйона осіб, що належали Ао 15 національностей» (Бишоп, 2009). ОАнією 3 таких національностей були етнічні росіяни - колишні громадяни СРСР. 
Аослідники А. Жуков та I. Ковтун цілком справеАливо вказують, що «росіяни воювали і в складі інших військових з'єАнань і частин СС» (Жуков і Ковтун, 2009).

Особливим Ажерелом поповнення військ СС було також російське козацтво. Козацькі військові частини почали створюватися ще наприкінці 1941 р. з військовополонених. 21 квітня 1943 р. німецьке командування виАало наказ про формування 1-ї козацької кавалерійської дивізії піА командуванням німецького генерала Гельмута фон Панвіца. Станом на Аистопал 1943 р. Ао iï складу входило 18555 вояків, з яких 14506 були козаками, 4099 - німці (Окороков, 1997). Високий рівень боєздатності козацької дивізії, ії успішні Аії проти югославських партизан привернули увагу командування СС. Навесні 1944 р. було створено ГУКВ (Hauptverwaltung der Kosakenheere), яке очолив російський генерал-цейтенант Петро Краснов. У березні ГУКВ піАпорядкували Головному управлінню CC (SS-Hauptamt - SS-HA). На початку вересня у відомстві Г. Гіммлера ухвалили рішення про переформування дивізії в 1-у козацьку кавалерійську Аивізію військ СС. 3 цією метою у Головному штабі СС було створено Резерв козацьких військ, який мав об’єднати всіх козаків. 5 вересня начальником цього спеціального органу призначили російського генерал-лейтенанта Андрія Шкуро. Ао Аивізії з різних фронтів почали прибувати російські козацькі частини. 4 листопада 1-а Козацька дивізія перейшла у підпорядкування Головного штабу військ СС (Генерал ВАасов: история предательства, 2015). 25 мютого 1945 р. це формування було перетворено на 15-й Козацький кавалерійський корпус військ CC (15. SSKosaken Kavallerie Korps). Г. фон Панвіц отримав звання групенфюрера СС. Чисельність з’єАнання на той час сягала 25 тис. осіб. Російські козаки воювали на боці нацистської Німеччини до ії капітуляції і здалися в полон британцям. I все ж, їх чекала видача раАянським представникам, які кваліфікували козацтво як «спеціальні партизанські частини німецьких СС» (Рейтлингер, 2011).

Певна кількість етнічних росіян служила піА керівництвом відомого німецького Аиверсанта Отто Скорцені, який вважав, що А. Гітлер «зробив велику помилку», недооцінюючи росіян (Скорцени, 2003). У 1942 р. РЗГА створило особливі курси «Оранієнбург» Аля піАготовки іноземців і Аобровольців із військ СС Ао Аиверсійної і партизанської діяльності, які у квітні 1943 р. очолив гауптштурмфюрер СС О. Скорцені. Росіяни служили у «Винищувальному з'єАнанні військ СС» (Waffen SS Jagdverband), створеному влітку 1944 р. Це був спеціальний орган Аля здійснення розвіАувальних, Аиверсійних і терористичних операцій, який перебував піА особистим 
контролем Г. Гіммлера. Наприкінці 1944 р. в м. Хохензальц було сформовано «Винищувальну команду Cxi丸» (Jagdverbend Ost), якій віАводилась особлива роль у здійсненні піАривної роботи проти СРСР. Це формування очолював штурмбанфюрер СС барон ААріан фон Фелькерзам - син адмірала флоту Російської імперії. Російські есесівці входили до складу двох груп, очолюваних російськими офіцерами Ігорем Решетніковим і Павлом Сухачовим. Згодом всі російські піАрозділи об’єАнали в Загальноросійську групу (Russland im gesand) піА командуванням штурмбанфюрера СС Х. Еберхарда. Наприкінці 1944 р. у складі «Винищувацьної команди Північ» (Jagdverbend Nord), Ао скцаАу якої входило чимало російських есесівців, було створено школу з піАготовки Аиверсантів, Ае викладачами працювали в основному росіяни - члени НТС (Смерш: исторические очерки и архивные документы, 2005).

У роки німецько-раАянської війни СС опікувалися й російською молОААю, прагнучі залучити іï Ао боротьби проти більшовизму. Це були Аіти, як емігрантів, так і тих росіян, які прибули на роботу до Німеччини з окупованої території СРСР. У статті «Російські вихованці SS», опублікованій в оАному з антираАянських виАань говорилося, що нацистські СС беруть на себе «шефство наА російською молоААю». Аалі повіАомАялося, що «всередині організації SS створюється особливий інститут «Російських вихованців SS», планується створення таборів Аля піАлітків віА 15 до 20 років, де віАбуватиметься 8-місячна військово-патріотична підготовка. Після закінчення курсів молодих російських есесівців чекала служба у допоміжних частинах мюфтваффе або навчання в офіцерських школах (Боляновський, 2014). АосліАник С. Чуєв стверАжує, що всі члени СРМ, створеного 7 травня 1944 р., «увійшли Ао склаАу помічників ППО і Аюфтваффе групи армій «Центр» (Вихованців СС)» (Чуев, 2004). Починаючи з березня 1944 р. аналогічна Аіяльність здійснюва^ася й на окупованій радянській території, Ае піА егідою СС вербувалася молодь віком віА 15 Ао 20 років Аля служби у Аопоміжній службі ППО. Спочатку їх називали «помічниками Аюфтваффе», а з 4 грудня 1944 р. - «вихованцями CC» («SS Zogling»). Чисельність цих молодих есесівців становила 1383 осіб (Аробязко, 1999). Отже, росіяни брали активну участь не тільки у складі дивізій військ СС, але й інших збройних формуваннях й організаціях СС.

УсвіАомлюючи наближення неминучої катастрофи через необхіАність вести війну на Ава фронти, керівництво III Райху погодилося на створення російського політичного центру, а також великих військових з'єАнань піА російським командуванням. За свідченням колишнього генерала РСЧА Василія Малишкіна, ще в березні 1944 р. райхсфюрер СС Г. Гіммлер взяв на себе 
«контроль і спостереження за Аіяльністю Російського комітету і взагалі всього російського визвольного руху...», а також заявив колишньому раАянському генерац-лейтенанту Андрію ВАасову, що він «... у подальшому повинен узгоджувати свої заходи не з представниками верховного командування збройних сим Німеччини, а тільки з управлінням СС» (Генерац В^асов: история предательства, 2015). 16 вересня 1944 р. після зустрічі А. Власова з Г. Гіммлером німецька сторона санкціонувала РВР і початок формування РВА. 14 листопаАа у Празі віАбувся установчий з’ізА КВНР, який проголосив об’єАнання всіх антирадянських сиц Аля боротьби «за нову вільну Росію», а також - створення 3С КВНР. За свілченням А. ВАасова, зустріч з Г. Гіммлером йому вцаштував обергруппенфюрер СС, начальник Головного управління СС Г. Бергер, який керував усіма закордонними антирадянськими організаціями. НаАалі Г. Бергер часто викликав А. Власова до себе, «цікавився й давав ... вказівки щодо створення КВНР і сформування РВА, а також через свого преАставника Крегера контролював виконання наданих Гіммлером і ним вказівок щодо антирадянської Аіяльності» (Генерац ВАасов: история предательства, 2015). Будучи довіреною особою Г. Гіммлера, оберфюрер військ СС Ерхард Крегер з вересня 1944 р. був представником СС при КВНР і постійно супроводжував А. Власова.

Отже, починаючи віА надання санкціi, РВР перебував піА пильним контролем СС і особистим патронатом райхсміністра Г. Гіммлера, який сподівався, що російські Аобровольці будуть воювати піА егіАою СС. Британський історик Аж. Рейтлінгер стверджує, Г. Гіммлер планував включити війська КОНР у структуру СС, але зрештою змушений був віАмовитися віА цієї ілеї, оскільки Аискредитований «бренА» СС не міг бути привабливим Аля залучення російських добровольців (Рейтлингер, 2011).

За цих умов, на початку мистопада 1944 р. колишня 29-а дивізія СС була передана до складу 3С КВНР. З’єАнання передислокували до м. Мюнзінген, де формувалася 1-а дивізія РВА, очолювана колишнім полковником РСЧА Сергієм Буняченко. Останній згодом свідчив, що «до складу дивізії повністю увійшла СС-івська бригада Російської визвольної народної армії...» чисельністю 6 тис. осіб. На ї основі «були сформовані артполк дивізіі, протитанковий Аивізіон, батальйон зв’язку і розвілувацьний Аивізіон». Крім того, до склаАу 1-ї Аивізіі увійшли частини вищезгаданої російської 30-ї гренадерської дивізії військ СС. За свіАченням С. Буняченка, чисельність цього контингенту становила до 3 тис. осіб (Генерал В Аасов: история предательства, 2015). Хоча, за іншими Ааними, зі складу 30-ї дивізії було переведено близько 
5 тис. вояків (Munoz, 1991). Не випаАково С. Буняченко кваліфікував свою Аивізію як «віАбірну». ААже, особовий склаА 1-ї дивізії 3С КВНР склаАався переважно з колишніх російських есесівців, які мали значний бойовий АосвіА. У складі 1-ї дивізії РВА вони брали участь у боях проти РСЧА на ОАерському фронті, надали допомогу учасникам Празького повстання у боротьбі з німцями у травні 1945 р. Й. Гоффманн піАкреслює, що у цей періоА колишні російські есесівці «виявили себе наАійними бійцями» (Хоффманн, 1990).

Ао співпраці з СС також залучались як деякі структурні піАрозділи, так і окремі діячі РВР. Так, у липні 1944 р. за наказом Г. Гіммлера поблизу м. Аьвова було створено організацію «Скорпіон», переА якою ставилось завдання підготовки антирадянської мітератури, спрямованої на дезорганізацію РСЧА. Ї̈̈ очолював фахівець з пропаганди штандартенфюрер СС Гюнтер А'Алькен, який перебував у безпосередньому піАпорядкуванні Г. Гіммлера. За свідченням колишнього генерала РСЧА Ф. Трухіна, на курси російських пропагандистів, які він очолював, «прийшла рознарядка про направлення до «Скорпіону» 20 пропагандистів Аля використання їх на цій антирадянській роботі». Ф. Трухін також свідчив, що «за завданням СС сформував окремий танкововинищувальний батальйон Аля оборони Берліна» (Генерал ВАасов: история предательства, 2015).

В. Шелменберг писав, що між СС і генералом А. ВАасовим існував «секретний Аоговір, який Аавав йому право на території Радянського Союзу мати власну секретну службу» і передавати «всю одержану віА своїх агентів інформацію». Начальник VI управління РЗГА пілкреслював, що «наші російські колеги, Аумаючи, що тепер вони борються за свою свободу, за нову Росію.., працювали з великим натхненням» (Шелменберг, 1991). Очевидно, визначити чисельність цієї категорії російських «колег» СС неможливо.

Отже, керівництво нацистських СС контролювало процес створення організації, становлення й діяльності РВР і ЗС КВНР, а також залучало Ао співпраці їхні структурні піАрозділи і окремих діячів.

ОАним з важливих аспектів вивчення проблеми співробітництва росіян 3 СС у роки німецько-радянської війни є встановлення їхньої чисельності. ОАнак, у науковій мітературі з цього приводу існують чималі розбіжності. Так, російський АосліАник В. Похльобкін стверджує, що в «елітних військах «СС» служили понаА 150 тисяч колишніх військовослужбовців» (Похлёбкин, 1997), проте не враховує Аобровольців з цивільного населення і тих, хто служив в інших піАрозділах СС. Український історик М. Гетьманчук вважає, що безпосередньо у військах СС служило не менше 150 тис. раАянських громадян. 
Водночас, він визнає, що сліА окремо враховувати учасників спеціальних піАрозділів СС, які «хоч і входили до склаАу військ СС, але знаходилися у піАпорядкуванні РЗГА» (Гетьманчук, 2018). І все ж, обидва вчених не вказують етнічну приналежність тих осіб, які співробітничали з СС. Натомість це спробував зробити досліАник А. Боляновський. Вважаючи, що «через різні збройні формування 3С Третього Райху пройшло щонайменше півмільйона росіян або понаА $1 / 3$ віА тих громадян СРСР, яких використовували на німецькій військовій та парамікітарній службі», він вказує, що у військах СС служили 27 тис. росіян. Водночас автор уточнює, що має на увазі кише Аві російські бригали, полк «Варяг», Аві російські Аивізії і Аопоміжний персонал в інших з'єлнаннях Ваффен-СС. ОАнак, визнаючи, що «80 000 росіян служили в козацьких формуваннях або як козаки «допоміжними Аобровольцями» на німецькій службі, автор не зараховує їх до складу формувань СС (Боляновський, 2012).

Очевидно, найближчими до з'ясування істини у цьому питанні є I. Ковтун i А. Жуков. Вони визначають «приблизну кількість росіян, які співробітничали з СС», у 100-120 тис. осіб. Водночас історики уточнюють, що ця цифра «не може бути абсолютно точною, оскільки в Аеяких випадках росіяни записувалися на службу як українці, білоруси, козаки, інгерманландці і т. А.» (Жуков і Ковтун, 2009). Отже, АосліАники мають на увазі, що реальна чисельність росіян-есесівців була більшою, ніж 120 тис. осіб.

На той факт, що етнічні росіяни видавали себе за представників інших слов'янських націонацьностей звертають увагу у своїх спогадах німецький офіцер Вільфріл Карл Стрік-Стрікфельлт (Strik-Strikfeldt, 1970), український військовий Аіяч Павло Шандрук (Шандрук, 1994) та ін. Це піАтверджують сучасні досліАники, зокрема, А. Боляновський, який вказує, що частина росіян у таборах військовополонених видавала себе за білорусів або українців, i, віАповіАно, вони часто потрапляли до українських чи білоруських військових формувань. Тому «вказати точну кількість російських бійців Вермахту, Ваффен-СС та інших родів військ Німеччини доволі склаАно» (Боляновський, 2012).

\section{Обговорення}

Загалом автор не претендує на остаточне розкриття зазначеної теми, піАкреслюючи, що кожен 3 розглянутих аспектів може бути преАметом обговорення й подацьшого грунтовного АосліАження, з'ясування й уточнення окремих фактів. Зокрема, це стосується проблеми встановцення максимально 
точної чисельності росіян, які співробітничали з СС, але приховували своє етнічне походження. САіА піАкреслити, що це питання може бути остаточно з'ясоване тільки після ретельного дослідження документів і матеріалів німецьких i, особливо, раАянських (сучасних російських) архівів. Крім того, предметом окремого АосліАження може бути питання співробітництва між нацистськими СС і радянським НКВС, яке почалось після піАписання радянсько-німецького договору 23 серпня 1939 р. і тривало до 1941 р.

У цьому зв’язку, Міжнародна конференція «Переосмислення історії: конфлікт фактів і гіпотез», організована чеським науковим журналом European Scientific e-Journal видавничого Аому Anisiia Tomanek OSVČ і покликана об’єАнати вчених 3 метою обміну досвіАом i результатами історичних дослілжень, може сприяти подальшому вивченню різних аспектів зазначеної проблематики.

\section{Висновки}

Таким чином, у результаті проведеного досліАження піАтверджено, що в роки німецько-радянської війни 1941-1945 рр. етнічні росіяни - громадяни СРСР - активно співробітничали 3 нацистською організацією СС. Значна частина 3 них стала на шлях колабораціонізму, сподіваючись на повалення більшовицького режиму. Аехто в умовах війни прагнув вижити, врятувати свої родини, зробити кар'єру тощо. Особливістю цього явища є той факт, що 3 боку Німеччини співробітництво з росіянами зАійснювацося на державному рівні з метою забезпечення інтересів нацистського режиму, натомість з боку росіян - це були переважно добровільні Аіi, обумовлені сподіванням на військову поразку СРСР. Аіапазон форм російсько-німецької співпраці у межах СС Аосить широкий - віА пропагандистської й розвіАувально-Аиверсійної роботи піА керівництвом спецслужб до участі у бойових діях у склаАі збройних формувань. Починаючи з 1941 р. Аесятки тисяч росіян служили у Аопоміжній службі поліції порядку на окупованій території СРСР, згодом - у збройних формуваннях СС: 29-й і 30-й «російських», а також 28-й, 33-й 36-й «іноземних» Аивізіях СС, 1-й Російській національній бригаді СС («Аружина»), Аобровольчому полку СС «Варяг», 15-у Козацькому кавалерійському корпусі військ СС, «Винищувальній команді СхіА» та ін. Водночас керівництво СС постійно контролювало процес створення організаціі, становцення й Аіяльності РВР і ЗС КВНР, а також залучало до співпраці їхні структурні пілрозділи і окремих діячів. Характерно, що росіяни брали активну участь не тільки у збройних формуваннях СС, але й у різних структурах цієї організаціі, 
зокрема, у проекті VI управління РЗГА «Цеппелін». Ао роботи у мавах СС залучалася також російська молодь - т. зв. «вихованці СС».

У результаті АосліАження виявлено значні розбіжності у науковій Аітературі щодо визначення чисельності росіян, які співробітничали з СС у роки німецько-радянської війни. У цьому зв’язку Аоводиться констатувати, що встановити точну кількість росіян, які служили в СС, АосліАникам поки що не вдалося. Проте, очевиАно, що чисельність росіян-есесівців становица не менше 120 тис. осіб.

\section{Список Ажерел інформації:}

Бишоп, К. (2009). Аивизии Ваффен-СС 1939-1945: Справочник-определитель техники. (Пер. с англ. С. Аробязко). Москва: Эксмо.

Боляновський, А. (2013). Іноземні військові формування у Збройних силах Німеччини (1939-1945 рр.). Аьвів: Видавництво мьвівської політехніки.

Боляновський, А. (2014, 10 вересня) Росіяни як 〈радянські військові колаборауіоністи» $\begin{array}{lllll}y & 1941-1945 & \text { p } & \text { Отримано } & 10.05 .2020\end{array}$ https://www.istpravda.com.ua/articles/2014/09/10/144608/

Боляновський, А. (2012). Українці, росіяни й поляки у Збройних силах Німеччини у 1939-1945 роках: порівняльний аналіз. Украйна-Польща: історична спадшина і суспільна свідомість, 5. Аьвів.

Генерал Власов: история предательства (2015). В 2 т.: В 3 кн. Под реА. А.Н. Артизова. Москва: Политическая энциклопедия. - Т. 1: Нацистский проект «Aktion Wlassow». - 1160 с.

Гетьманчук, M. (2018). Іноземні громадяни у військових формуваннях СС нацистської Німеччини (1939-1945 pр.). Historical and Cultural Studies, 5, 1, 23 34. Lviv: Lviv Politechnic Publishing House.

Гкаубе, Г. (2007). Загадочная смерть бригадефюрера Каминского. (Пер. с нем.) Эхо войнъг, 1.

Гончаренко, О.Г. (2005). Белоэмигранты между звездой и свастикой. Москва.

Аробязко, С.И. (1999). Вторая мировая война 1939-1945. Русская освободительнал армия. Москва: «Фирма «Издательство АСТ»», 1999.

Аробязко, С.И., Романько, О.В., Семёнов, К.К. (2011). Иностраннъге формирования Третьего рейха. Иностранив на службе начизма: история европейского коллаборачионизма. Москва: АСТ; Астрель; Харвест, 2011.

Ермолов, И. (2010). Три года без Сталина. Оккупачия: советские граждане между начистами и большевиками. 1941-1944. Москва: ЗАО Центрполиграф. 
Жуков, А. (2014, 2 июля). ПеSSни партизан. Совершенно секретно.

Жуков, А.А., Ковтун, И.И. (2019). Аважды предавшие. Бригада СС «Аружина». Москва: Вече.

Жуков, А.А., Ковтун, И.И. (2013). Охотники за партизанами. Бригада Аирлевангера. Москва: Вече.

Жуков, А.А., Ковтун, И.И. (2010). Руские эсэсовивг. Москва: Вече.

Жуков, А., Ковтун, И. (2009). Русские эсэсовчьг в бою. Солдаты или каратели? Москва: Яуза-пресс.

Киндер, Г., Химьгеман, В. (2003). Всемирная история. (Пер. с нем.) Москва: Рыбари.

Косик, В. (1996). Украӥна і Німеччина у Аругій світовій війні. Париж-Нью-ЙоркАьвів: НТШ імені Т. Шевченка.

Окороков, В.А. (1997). Казаки и русское освободительное Авижение. В поисках истины. Пути и судъбъ второй эмиграуии. Москва: ИАИ РГГУ.

Пивовар, С.Ф. (2021). Російська визвольна народна армія у німецько-радянській війні. World science: problems, prospects and innovations. Abstracts of the 6th International scientific and practical conference. Perfect Publishing, 557-566. Toronto, Canada. Отримано 03.04.2021 за https://sci-conf.com.ua/vi-mezhdunarodnayanauchno-prakticheskaya-konferentsiya-world-science-problems-prospectsand-innovations-23-25-fevralya-2021-goda-toronto-kanada-arhiv/

Похлёбкин, В.В. (1997). Великая война и несостоявшийся мир. 1941-1945-1994: Военный и внешнеполитический справочник. Можайск: Арт-Бизнес-Центр.

Рейтлингер, Аж. (2011). Цена предательства. Сотрудниество с врагом на оккупированных территориях СССР. 1941-1945. (Пер. с англ.) Москва: ЗАО Центрполиграф.

Романько, О. (2008). 30-я Гренадерская Аивизия войск СС (к истории иностранных формирований в составе германских вооруженных сил). Сторінки воєнної історї Украйни, 11, 309-320.

Русские в ПреАприятии «Цеппелин» (2009, 27 ноября). Отримано 15.02.2020 за http://rnns.ru/100038-russkie-v-predpriyatii-ceppelin.html

Русские эсэсовцы в боях за Варшаву: к годовщине августовских событий 1944 г. (2012, 11 августа). Отримано 05.10.2020 за URL: https://fotohistory.livejournal.com/2516471.html

Сборник справочных материалов об органах германской развеАки, Аействовавших против СССР в период Великой Отечественной войны 1941-1945 гг. (2012) Отримано 19.06.2020 за URL: http://kopilka.wolfschanze.ru/sbor.htm 
Семёнов, К.К. (2008). Русские фюреры СС. Эхо войнъъ, 2.

Семиряга, М.И. (2000). Коллаборачионизм. Природа, типология и проявления в годьг Второй мировой войны. Москва: РОССПЭН.

Скорцени, О. (2003). Неизвестная война: воспоминания. (пер. с фр.) Минск: Попурри.

Смери: исторические очерки и архивные документы (2005). Москва: ОАО «Моск. учебники и картолитография».

Соколов, Б.В. (2000). Тайнъ Второй мировой. Москва: Вече.

СС в действии. Аокументы о преступлениях СС (1960). (пер. с нем.) Москва: ИзА-во иностранной мит-ры, 1960.

Хоффманн, Й. (1990). История власовской армии. (пер. с нем. Е. Гессен) Париж: YMCA-PRESS.

Чуев, С. (2004). Проклатыле солдатыл. Москва: ЭКСМО.

Чуев, С.Г. (2003). Спечслужбъг Третьего Рейха. Книга 2. Санкт-Петербург: Издательский Аом «Нева».

Шандрук, П. (1994). Правда про 1-шу Українську дивізію і Українську Національну Армію. Українська Аивізія «Галичина». Історикопубліцистичний збірник, 62-75. Київ; Торонто.

Шемленберг, В. (1991). Секретнал служба Гитлера: Мемуары начальника управления шпионажа и диверсий службы безопасности СА. (пер. с англ.) Київ: «Аоверие».

Munoz, A.J. (1991). Forgotten Legions: Obscure Combat Formations of the Waffen-SS. New York: Axis Europa. Books.

Strik-Strikfeldt, W. (1970). Against Stalin and Hitler: Memoir of the Russian Liberation Movement, 1941-1945. New York. 